\title{
Interleukin (IL) 4 and IL-13 Act on Human Lung Fibroblasts Implication in Asthma
}

\author{
Christelle Doucet, ${ }^{*}$ Danièle Brouty-Boyé, ${ }^{\star}$ Corine Pottin-Clémenceau, ${ }^{\star}$ Giorgio Walter Canonica, ${ }^{\ddagger}$ Claude Jasmin, ${ }^{\star}$ \\ and Bruno Azzarone* \\ *U268 INSERM Hôpital Paul Brousse, 94807 Villejuif Cedex, France; and ${ }^{\ddagger}$ Allergology and Clinical Immunology, DIMI, University of \\ Genoa, 16132 Genoa, Italy
}

\begin{abstract}
Airway hyperresponsiveness leading to subepithelial fibrosis is mediated by inflammatory cells activated by $\mathrm{T}$ helper (Th) 2-derived cytokines such as IL-4 and IL-5. By analyzing the phenotype and response of human lung fibroblasts derived from either fetal (ICIG7) or adult (CCL202) tissue as well as from a Th2-type stromal reaction (FPA) to IL-4 and IL-13, we provide evidence that human lung fibroblasts may behave as inflammatory cells upon activation by IL-4 and IL-13. We show that the three types of fibroblasts constitute different populations that display a distinct pattern in cell surface molecule expression and proinflammatory cytokine and chemokine release. All fibroblasts express functional but different IL-4/IL-13 receptors. Thus, while IL-4 receptor (R) $\alpha$ and IL-13R $\alpha 1$ chains are present in all the cells, CCL202 and FPA fibroblasts coexpress the IL$13 R \alpha 2$ and the IL-2R $\gamma$ chain, respectively, suggesting the existence of a heterotrimeric receptor (IL-4R $\alpha / \mathrm{IL}-13 \mathrm{R} \alpha / \mathrm{IL}-$ $2 R \gamma$ ) able to bind IL-4 and IL-13. Stimulation with IL-4 or IL-13 triggers in the fibroblasts a differential signal transduction and upregulation in the expression of $\beta 1$ integrin and vascular cell adhesion molecule 1 and in the production of IL-6 and monocyte chemoattractant protein 1, two inflammatory cytokines important in the pathogenesis of allergic inflammation. Our results suggest that when activated by IL-4 and IL-13, different subsets of lung fibroblasts may act as effector cells not only in the pathogenesis of asthma but also in lung remodeling processes. They may also differentially contribute to trigger and maintain the recruitment, homing, and activation of inflammatory cells. ( $J$. Clin. Invest. 1998. 101:2129-2139.) Key words: human lung fibroblasts - signal transduction - adhesion molecules • proinflammatory cytokines • airway inflammation
\end{abstract}

\section{Introduction}

Asthma is a complex disorder characterized by airway hyperresponsiveness and inflammation that may lead to the establishment of a diffuse and irreversible subepithelial fibrosis (1).

Address correspondence to B. Azzarone, U268 INSERM, Hôpital P. Brousse, 16, Av. P.V. Couturier, 94807 Villejuif Cedex, France. Phone: 01-45-59-53-12; FAX: 01-45-59-53-29.

Received for publication 27 May 1997 and accepted in revised form 4 March 1998.

J. Clin. Invest.

(C) The American Society for Clinical Investigation, Inc. 0021-9738/98/05/2129/11 \$2.00

Volume 101, Number 10, May 1998, 2129-2139

http://www.jci.org
The airway inflammation of asthma has been defined recently by the World Health Organization as "chronic inflammatory disease of the airways" and summarized by chronic infiltration and activation of several types of inflammatory cells in the bronchial mucosa, particularly $\mathrm{T}$ lymphocytes, defined as helper type 2 phenotype $(\mathrm{Th} 2)^{1}$ by their cytokine profile, eosinophils, and activated mast cells (2-5). When activated, these cells induce mediators of inflammation and cytokines such as IL-4, IL-5, IL-10, and GM-CSF, which amplify the inflammatory response and may remodel lung architecture (for a review, see reference 6). Activation of lung fibroblasts by inflammatory cells is associated with an increased deposition of collagen and fibronectin, causing the thickening of the basal membrane and the appearance of a diffuse subepithelial fibrosis $(1,7)$. It has been shown previously that IL-4 may increase DNA synthesis, collagen, fibronectin and tenascin deposition in human skin fibroblasts $(8,9)$. Therefore, it is possible that some of the effects of IL-4 on asthmatic airway hyperresponsiveness can result from a direct and specific action of the cytokine on lung fibroblasts.

Fibroblasts constitute a heterogeneous family of cells that express different phenotypic and functional features depending on their site of origin (10). For instance, murine lung fibroblasts constitute a mixture of cellular subsets expressing different functional markers of lymphoid cells, notably CD4 and thymocyte (Thy) 1 antigens $(11,12)$, and probably exert different immune functions. In human lung fibroblasts, expression of an IL-2 receptor (IL-2R $\alpha \beta$ ) that is functional even in the absence of the $\gamma_{c}$ chain has been demonstrated (13). Because this $\gamma$ chain is also a functional component of the IL-4, IL-7, IL-9, and IL-15 receptors (14-18), it is possible that human lung fibroblasts have developed alternative pathways that allow a cytokine-specific response.

In lymphoid cells, the IL-4 receptor is a heterodimer composed of the IL-4R $\alpha(140-\mathrm{kD})$ and the IL-2R $\gamma(65-\mathrm{kD})$ chain. By contrast, in nonlymphoid cells, another IL-4R has been characterized recently which is probably composed of the IL$4 \mathrm{R} \alpha$ chain and either the IL-13R $\alpha 1$ or IL-13R $\alpha 2$ chain (19, 20). These observations may partly explain why human IL-13 shares several biological activities with IL-4 (for a review, see reference 21).

In this study, we analyzed three human lung fibroblastic strains derived from normal tissues and from a Th2-type stromal reaction. We show that these cells constitute three distinct fibroblastic populations which differ in the expression of func-

1. Abbreviations used in this paper: $\alpha$-SMA, $\alpha$-small muscle actin; GAM, goat anti-mouse; MCP, monocyte chemoattractant protein; $\mathrm{R}$, receptor; RANTES, regulated upon activation, normal T cell expressed and secreted; RT, reverse transcription; SCF, stem cell factor; Th, T helper; Thy, thymocyte; VCAM, vascular cell adhesion molecule. 
tional surface antigens and in the production of cytokines and chemokines generally associated with inflammation and leukocyte recruitment (22-24). Moreover, they all express functional but different IL-4/IL-13 receptors and respond differently to IL-4 and IL-13, as evidenced by distinct pattern in tyrosine phosphorylation and upregulation of adhesion molecule and inflammatory cytokine production.

Overall, our results suggest that IL-4 and possibly IL-13 act directly on lung fibroblasts, which through their phenotypic heterogeneity may trigger and maintain differentially the recruitment, homing, and activation of inflammatory cells. This is of particular interest in light of two recent reports that demonstrate germinal center formation in the lung upon antigen stimulation (25) and recruitment of dendritic cells into the airway epithelium (26).

\section{Methods}

Cells. The origin and characteristics of the human fetal lung fibroblasts ICIG7 have been reported elsewhere (27). The human adult lung fibroblasts CCL202 were purchased from American Type Culture Collection (Rockville, MD). The primary adult lung fibroblasts FPA were derived from a Th2-type stromal reaction to a lung metastasis and established in culture as described previously (28). The two types of cells emerging in culture were $(a)$ cells growing in suspension and identified as CD4 lymphocytes bearing the Th2 phenotype (IL- $4^{+}, \mathrm{IL}_{-} 5^{+}$, and IL-2 ${ }^{-}$) and (b) adherent bipolar cells (FPA). All cells were cultured in DME (EuroBio S.A., Les Ulis, France) supplemented with $10 \%$ FCS (Biological Industries, Kibbutz Beit Haemek, Israel), $2 \mathrm{mM}$ glutamine, and $1 \%$ antibiotics (GIBCO BRL, Cergy-Pontoise, France) in a $37^{\circ} \mathrm{C}, 5 \% \mathrm{CO}_{2}$ incubator.

Cytokines. Human recombinant IL-4 and IL-13 were a generous gift from Schering-Plough Laboratory (Dardilly, France) and Sanofi Recherche (Labège Innopole, France), respectively. Human recombinant IL-2 and IFN- $\gamma$ were kindly provided by Hoechst-MarionRoussel (Romainville, France). Human recombinant IL-15 and
TNF- $\alpha$ were purchased from Tebu (Le Perray en Yvelines, France) and R\&D Systems (Abingdon, UK), respectively.

Antibodies. The various mAbs used were as follows: mAbs CDw124 (IL-4R $\alpha$ ), CD106 (vascular cell adhesion molecule [VCAM] 1), CD117 (c-kit/stem cell factor [SCF] receptor), CD4 mAb 13B8.2, and FITC goat anti-mouse (FITC-GAM) IgG were purchased from Immunotech (Marseille, France); CD40 mAb EA-5, mAb CDw90 (Thy-1), and anti-HLA-DR mAb L243 were purchased from Diaclone (Besançon, France), Becton Dickinson (Le Pont du Claix, France), and PharMingen (San Diego, CA), respectively; mAb AS02, specific for human fibroblasts, and CD31, specific for endothelial cells (mAb JC/70A), were purchased from Dianova GmbH (Hamburg, Germany) and Dakopatts A/S (Glostrup, Denmark), respectively; purified anticollagen I, III, and V goat and FITC anti-goat IgG were obtained from Southern Biotechnology Associates, Inc. (Birmingham, AL); antiphosphotyrosine mAb (P-Tyr) 4G10 from Upstate Biotechnology, Inc. (Lake Placid, NY); anti- $\beta 1$ integrin $\mathrm{mAb}$ C9 and anti-ED-B fibronectin variant $\mathrm{mAb} \mathrm{BC}-1$ were generously provided by Dr. L. Zardi (I.S.T., Genoa, Italy) and anti- $\alpha$-smooth muscle actin ( $\alpha$-SMA) mAb 1A4 by Dr. G. Gabbiani (Department of Pathology, University of Geneva, Geneva, Switzerland); anti-IL-2R $\beta$ $\mathrm{mAb}$ MIK $\beta 1$ and anti-IL-13R $\alpha 2 \mathrm{mAb}$ BA34 were kindly provided by Dr. M. Tsudo (Tokyo Metropolitan Institute of Medical Science, Tokyo, Japan) and Dr. J. Withness (Diaclone), respectively; antiIL-2R $\gamma$ mAbs 3B5 and 3G11 were a generous gift from Dr. J. Ritz (Dana Farber Cancer Institute, Boston, MA).

Indirect immunofluorescence analysis of fibroblast and cell surface proteins. For the detection of cytoskeletal and extracellular matrix elements, trypsinized cells were seeded onto eight-chamber Lab-Tek glass slides (Nunc, Inc., Naperville, IL), fixed with methanol, and proceeded as described previously (28). For cell surface molecule expression, adherent cells were detached with a nonenzymatic cell dissociation solution (GIBCO BRL) and incubated with saturating concentrations of unlabeled primary mAbs. After washing, cells were incubated with FITC-GAM and fixed with $1 \%$ formaldehyde in PBS. All incubations were performed for $30 \mathrm{~min}$ at $4^{\circ} \mathrm{C}$. As control, cells were incubated under similar conditions with murine $\mathrm{Ig}$ of the same isotype followed by FITC-GAM. Analysis of cell labeling was carried

Table I. Sequences of Amplification Primers

\begin{tabular}{|c|c|c|c|c|}
\hline Genes & Primers & Product size & Annealing temperature & Cycle no. \\
\hline & & $b p$ & ${ }^{\circ} \mathrm{C}$ & \\
\hline \multirow[t]{2}{*}{ IL-6 } & 5'-ATG AAC TCC TTC TCC ACA AGC GC-3' & 597 & 68 & 30 \\
\hline & 5'-GAA GAG CCC TCA GGC TGG ACT G-3' & & & \\
\hline \multirow[t]{2}{*}{ IL-13R $\alpha 1^{*}$} & 5'-AGG ATG ACA AAC TCT GGA G-3' & 358 & 58 & 30 \\
\hline & 5'-CTC AAG GTC ACA GTG AAG G-3' & & & \\
\hline \multirow[t]{2}{*}{ IL-13R $\alpha 2 *$} & 5'-ATA CCT TTG GGA CCT ATT CC-3' & 426 & 58 & 30 \\
\hline & 5'-TGA ACA TTT GGC CAT GAC TG-3' & & & \\
\hline \multirow[t]{2}{*}{ IL-4R $\alpha$} & 5'-GAC CTG GAG CAA CCC GTA TC-3' & 335 & 53 & 35 \\
\hline & 5'-CAT AGC ACA ACA GGC AGA CG-3' & & & \\
\hline \multirow[t]{2}{*}{ IL-2R $\gamma$} & 5'-CCA GGA CCC ACG GGA ACC CA-3' & 481 & 60 & 35 \\
\hline & 5'-GGT GGG AAT TCG GGG CAT CG-3' & & & \\
\hline \multirow[t]{2}{*}{ IL-3 } & 5'-ATG AGC CGC CTG CCC GTC CTG A-3' & 449 & 60 & 35 \\
\hline & 5'-GCG AGG CTC AAA GTC GTC TGT TG-3' & & & \\
\hline \multirow[t]{2}{*}{ Eotaxin } & 5'-TGA AGG TCT CCG CAG CAC TTC TGT-3' & 226 & 63 & 35 \\
\hline & 5'-TGG GGT CGG CAC AGA TAT CCT TGG G-3' & & & \\
\hline \multirow[t]{2}{*}{ SCF } & 5'-CCC AGG CTC TTT ACT CCT GAA-3' & 348 & 60 & 35 \\
\hline & 5'-CTG CCC TTG TAA GAC TTG GCT G-3' & & & \\
\hline \multirow[t]{2}{*}{ GAPDH } & 5'-GGT GAA GGT CGG AGT CAA CGG A-3' & 240 & 63 & 19 \\
\hline & 5'-GAG GGA TCT CGC TCC TGG AAG A-3' & & & \\
\hline
\end{tabular}

*Provided by Sanofi Recherche. 
out on a FacsCalibur ${ }^{\circledR}$ cytometer (Becton Dickinson). At least 5,000 cells were analyzed in each test.

Detection of cytokine/chemokine production. Soluble cytokines and chemokines were quantified in cell-free culture supernatants using standard ELISA kits (R\&D Systems and Immunotech) according to the manufacturers' instructions. The lower limit of detection was 1-8 $\mathrm{pg} / \mathrm{ml}$.

Detection of cytokines and cytokine receptors by reverse transcription (RT) PCR. Primers for the chemokines RANTES (regulated upon activation, normal $\mathrm{T}$ cell expressed and secreted), IL-8, and monocyte chemoattractant protein (MCP) 1, the adhesion molecule VCAM-1, and the cytokine GM-CSF were purchased from R\&D Systems and used according to the manufacturer's instructions. The primer for IL-11 was purchased from Clontech (Ozyme, MontignyLe-Bretonneux, France). The primer sequences for the chemokine MCP-4 were designed and used as reported (29). The other human sets of primers are listed in Table I.

Total RNA was isolated using TRIzol reagent (GIBCO BRL) according to the manufacturer's specifications. cDNA was synthesized from total RNA using oligo-dT primer and Moloney murine leukemia virus reverse transcriptase (GIBCO BRL) according to the manufacturer's instructions. In each PCR reaction, $1 \mu \mathrm{Ci} /$ tube of $\left[\alpha-{ }^{32} \mathrm{P}\right] \mathrm{dCTP}$ was included to label the PCR product. Aliquots of the RT-PCR reaction were separated by PAGE. The gel was dried, and the results were visualized by autoradiography as described (13). Water was used as a negative control for contamination, and some samples were amplified without reverse transcription to check for the presence of DNA contaminants.

Cross-linking experiments. Cells were washed twice in TE buffer (Tris $10 \mathrm{mM}$, EDTA $1 \mathrm{mM}, \mathrm{pH} 7.4$ ) and resuspended at $3 \times 10^{6}$ cells/ $\mathrm{ml}$ in DME containing $1 \%$ BSA and Hepes, $\mathrm{pH}$ 7.4. Cells were preincubated for $1 \mathrm{~h}$ at $4^{\circ} \mathrm{C}$ with either a 100-fold excess of unlabeled IL-2, IL-4, IL-13, or IL-15, and blocking mAbs CDw124 (IL-4R $\alpha$ ), MIK $\beta 1$ (IL-2R $\beta$ ), and $3 \mathrm{G} 11$ (IL-2R $\gamma$ ). The binding was performed in the presence of $1 \mathrm{nM}$ or $250 \mathrm{pM}^{125} \mathrm{I}-\mathrm{IL}-4$ (DuPout de Nemours, NEN Division, Dreiech, Germany) for $2 \mathrm{~h}$ at $4^{\circ} \mathrm{C}$. In some cases, an additional 30-min incubation time at $37^{\circ} \mathrm{C}$ was used to detect cytokine receptor internalization. After binding, the cross-linker agent disuccinimidyl suberate dissolved in DMSO was added at $270 \mu \mathrm{M}$ to the mixture for $30 \mathrm{~min}$ at $4^{\circ} \mathrm{C}$. The reaction was quenched by adding ammonium acetate $10 \mathrm{mM}$. After washing, cells were lysated with buffer containing $0.5 \% \mathrm{NP}-40, \mathrm{NaCl} 300 \mathrm{mM}$, Tris $50 \mathrm{mM}$ (pH 7.4), EDTA $1 \mathrm{mM}$, and protease inhibitors for $30 \mathrm{~min}$ at $4^{\circ} \mathrm{C}$. The lysates were centrifuged at $15,000 \mathrm{~g}$ for $15 \mathrm{~min}$ at $4^{\circ} \mathrm{C}$, the pellet was discarded, and the supernatant was analyzed in a 10 or $15 \%$ SDS-PAGE gel under reducing conditions as described (30). The gel was fixed, dried, and exposed on a $\mathrm{x}$-ray film for $1-2 \mathrm{wk}$ at $-70^{\circ} \mathrm{C}$.

Detection of protein tyrosine phosphorylation in IL-4/IL-13-stimulated fibroblasts by Western blot. Confluent cell cultures were incubated overnight in serum-free DME at $37^{\circ} \mathrm{C}$. Cells were then washed with the serum-free medium containing $50 \mu \mathrm{M}$ orthovanadate $\left(\mathrm{Na}_{3} \mathrm{VO}_{4}\right)$ and stimulated with $100 \mathrm{ng} / \mathrm{ml}$ of either IL-4 or IL-13, FCS $(10 \%)$, or serum-free medium for $10 \mathrm{~min}$ at $37^{\circ} \mathrm{C}$. Cells were washed twice and resuspended in lysis buffer as described (31). The samples were analyzed in $7.5 \%$ or $5-17.5 \%$ SDS-PAGE and transferred to PVDF membranes (Dupont-NEN). The membranes were then saturated with 5\% BSA (Sigma Chemical Co., St. Quentin Fallavier, France), probed with anti-P-Tyr mAb 4G10 followed by goat peroxidase-conjugated anti-mouse IgG (Immunotech), and visualized by an ECL system (Amersham International, Les Ulis, France).

\section{Results}

Phenotype of human lung fibroblasts. As summarized in Table II, immunofluorescent staining revealed that in ICIG7 cultures, a few cells (10-15\%) stained positively for the myofibroblastic $\alpha$-SMA marker, whereas the expression of ED-B
Table II. Immunophenotype of Human Lung Fibroblasts

\begin{tabular}{|c|c|c|c|}
\hline \multirow[b]{2}{*}{ Antigens } & \multicolumn{3}{|c|}{ Human lung fibroblasts } \\
\hline & ICIG7 & CCL202 & FPA \\
\hline \multicolumn{4}{|c|}{ Cytoskeletal and matrix elements } \\
\hline$\alpha$-SMA & + & + & +++ \\
\hline ED-B fibronectin & +++ & - & +++ \\
\hline \multicolumn{4}{|l|}{ Collagens } \\
\hline Type I & ++ & ++ & + \\
\hline Type III & ++ & ++ & + \\
\hline Type V & ++ & ++ & ++ \\
\hline \multicolumn{4}{|l|}{ Cell surface antigens } \\
\hline ASO2 & +++ & +++ & +++ \\
\hline CD31 & - & - & - \\
\hline Thy-1 & +++ & +++ & +++ \\
\hline$\beta 1$ integrin & +++ & +++ & +++ \\
\hline CD4 & + & + & - \\
\hline $\mathrm{c}-k i t$ & + & + & - \\
\hline CD40 & - & - & + \\
\hline VCAM-1 & - & + & - \\
\hline HLA-DR & - & - & - \\
\hline
\end{tabular}

,,++++++ , Staining relative to isotype controls.

fibronectin variant was homogeneous. A similar small percentage of $\alpha$-SMA-expressing cells was observed in CCL202 cultures, but no ED-B fibronectin was detected. Unlike ICIG7 and CCL202, 100\% of FPA fibroblasts expressed $\alpha$-SMA and showed strong positivity for ED-B fibronectin. The coexpression of these two markers has been reported both in vitro and in vivo as typical of activated fibroblasts (myofibroblasts) involved in stromal reactions and fibrotic lesions $(10,28,32)$. Thus, FPA cells could resemble the lung myofibroblasts generated in a Th2-derived cytokine environment (see Methods) such as those responsible for the subepithelial fibrosis of asthma. In addition to the above markers, all fibroblasts ex-

Table III. Production and Transcription of Cytokines/Chemokines in Human Lung Fibroblasts

\begin{tabular}{|c|c|c|c|c|c|c|}
\hline \multirow[b]{3}{*}{ Cytokines } & \multicolumn{6}{|c|}{ Human lung fibroblasts } \\
\hline & \multicolumn{2}{|c|}{ ICIG7 } & \multicolumn{2}{|c|}{ CCL202 } & \multicolumn{2}{|c|}{ FPA } \\
\hline & Protein* & Transcript & Protein & Transcript & Protein & Transcript \\
\hline IL-6 & 1.75 & + & 2.75 & ++ & 4.25 & +++ \\
\hline IL-11 & 0.30 & + & 0.06 & \pm & 0.35 & + \\
\hline GM-CSF & 0.85 & + & 0 & - & 0 & - \\
\hline $\mathrm{SCF}$ & NT & + & NT & + & NT & + \\
\hline IL-3 & NT & - & NT & \pm & NT & - \\
\hline IL-8 & 3.50 & ++ & 1.50 & + & 1.50 & + \\
\hline MCP-1 & 4.50 & +++ & 1.90 & ++ & 0.50 & + \\
\hline RANTES & 0 & - & 0 & - & 0 & - \\
\hline Eotaxin & NT & + & NT & + & NT & + \\
\hline MCP-4 & NT & + & NT & + & NT & - \\
\hline
\end{tabular}

*Average production $(\mathrm{ng} / \mathrm{ml})$ over a 3 -d time period in culture. +++ , ,+++ , Relative abundance of transcripts. NT, Not tested. 
pressed collagen I, III, and V. They also stained positively ( $100 \%$ positive cells in all three cultures) for human fibroblast membrane antigen AS02, and were found to be negative for endothelial CD31 marker (Table II).

Different fibroblastic subsets have been identified in murine lung fibroblasts on the basis of the differential expression of membrane antigens such as Thy-1, CD4, or HLA class II $(11,12)$. By using a large panel of mAbs, we found that all types of fibroblasts highly expressed Thy- 1 antigen and $\beta 1$ integrin (Table II). Moreover, while CD4 and c-kit were expressed in ICIG7 and CCL202 fibroblasts, no expression was detected in FPA cells. An even more restricted expression was observed with the other two membrane antigens, CD40, expressed in FPA fibroblasts, and VCAM-1, in CCL202 fibroblasts. Furthermore, no expression of HLA-DR was detected, whatever the fibroblast's origin (Table II). However, addition of $200 \mathrm{IU} / \mathrm{ml}$ of IFN- $\gamma$ to the cultures revealed an average of 78,52 , and $33 \%$ of HLA-DR-positive cells in FPA, ICIG7, and CCL202 cultures, respectively (data not shown).

Cytokine production. As seen in Table III, all three types of fibroblasts produced relatively high but varied levels of IL-6, IL-11, IL-8, and MCP-1 as assayed by ELISA. By contrast, no production of RANTES was detected, and GM-CSF was produced in ICIG7 fibroblasts only. RT-PCR analyses generally demonstrated a good correlation between the presence or ab-
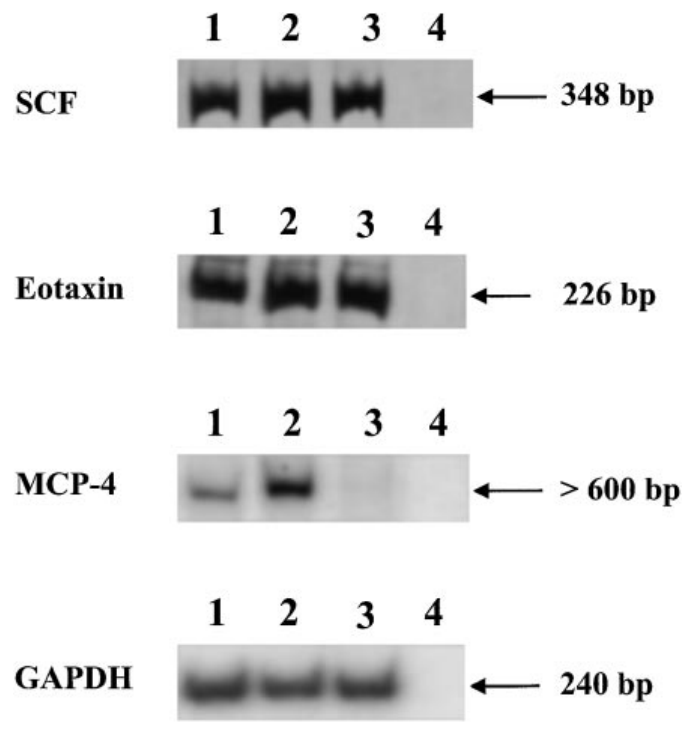

Figure 1. RT-PCR analysis of SCF, eotaxin, MCP-4, and GAPDH transcripts in human lung fibroblasts. ICIG7 (lane 1), CCL202 (lane 2), FPA (lane 3) fibroblasts and negative control (lane 4). GAPDH transcripts were used as positive control. Arrows, Size of the amplification products (bp). Each autoradiogram is representative of at least three different experiments.
A

IL-4R $\alpha$
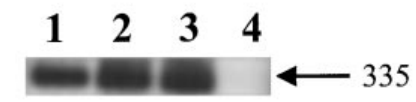

IL-13R $\alpha 1$
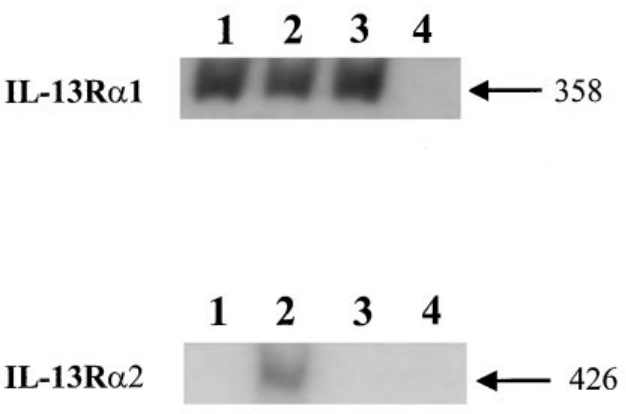

IL-2R $\gamma$

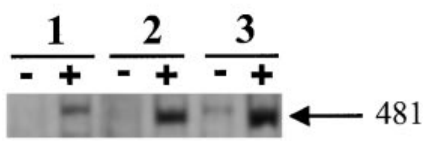

GAPDH
B
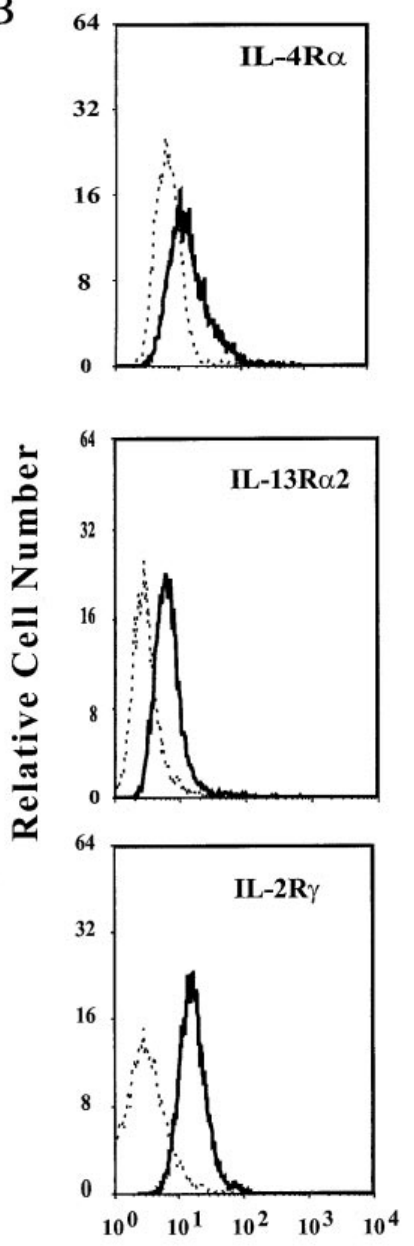

Fluorescence Intensity
Figure 2. Analysis of IL-4/IL-13 receptors in human lung fibroblasts. ( $A$ ) RT-PCR analysis of IL-4R $\alpha$, IL-13R $\alpha 1$, IL-13R $\alpha 2$, and IL-2R $\gamma$ transcripts in ICIG7 (lane 1), CCL202 (lane 2), and FPA (lane 3) cells and negative control (lane 4). Detection of IL-2R $\gamma$ in the absence $(-)$ and presence (+) of $10 \mu \mathrm{g} / \mathrm{ml}$ cycloheximide. Arrows, Size of the amplification products (bp). $(B)$ Flow cytometric analysis of IL-4R $\alpha$, IL-13R $\alpha 2$, and IL-2R $\gamma$ chain expression (solid lines) in ICIG7, CCL202, and FPA, respectively. Controls were performed with an irrelevant isotype $\operatorname{IgG}$ (broken lines). Mean fluorescence intensity was analyzed with Cellquest software (Becton Dickinson). Each histogram is representative of at least three different experiments. 


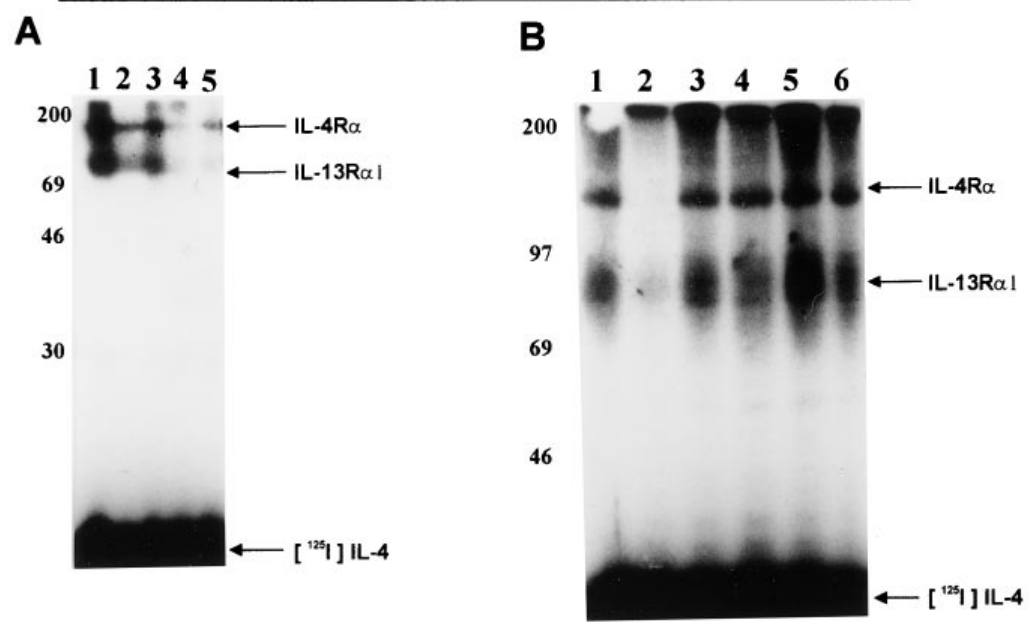

CCL202

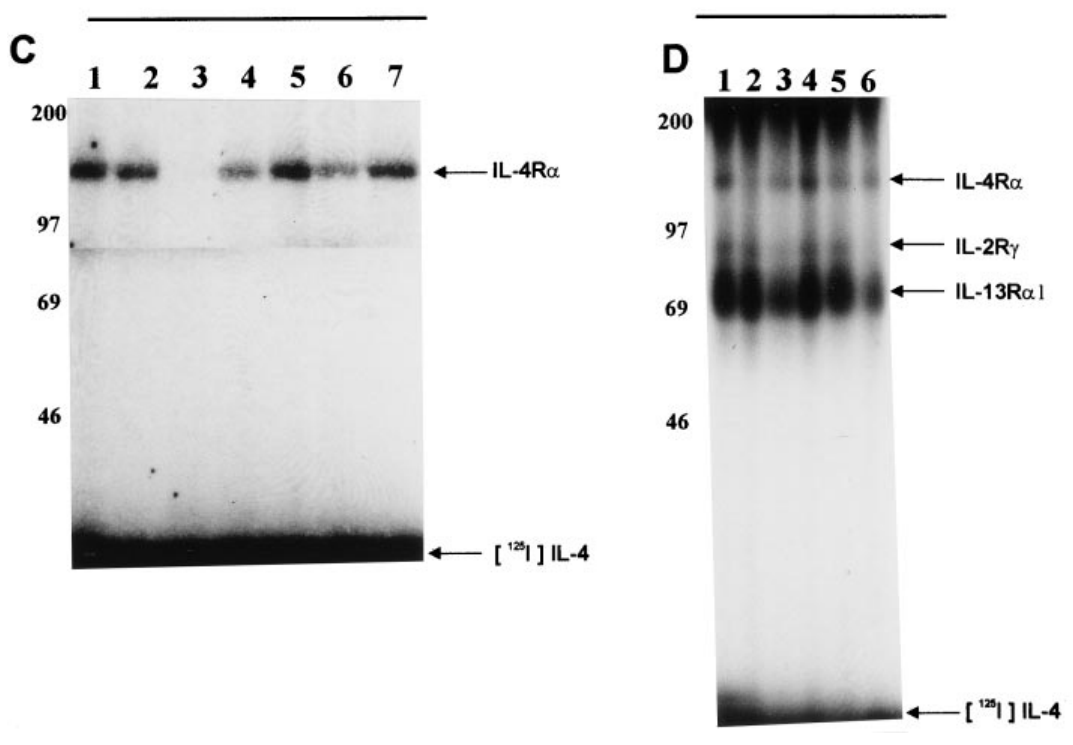

Figure 3. Affinity labeling cross-linking of IL-4R complexes by ${ }^{125} \mathrm{I}-\mathrm{IL}-4$ in human lung fibroblasts. (A) ICIG7 fibroblasts were incubated with $1 \mathrm{nM}$ (lane 1) and $250 \mathrm{pM}$ (lane 2) of ${ }^{125} \mathrm{I}-\mathrm{IL}-4$. Internalization of IL-4/IL-4R complex was determined after further incubation of labeled cells at $37^{\circ} \mathrm{C}$ for $30 \mathrm{~min}$ (lane 3 ). Competition experiments were performed with an excess of unlabeled IL-4 (lane 4) and IL-13 (lane 5). (B) ICIG7 fibroblasts were incubated under the same conditions as above with either ${ }^{125} \mathrm{I}-$

IL-4 (lane 1) or in the presence of an excess of unlabeled IL-4 (lane 2), IL-2 (lane 3), IL-15 (lane 4), and blocking mAbs MIK $\beta 1$ (anti-IL-2R $\beta$, lane 5) and 3G11 (anti-IL-2R $\gamma$, lane 6). (C) CCL202 fibroblasts were incubated with either $1 \mathrm{nM}$ (lane 1 ) or $250 \mathrm{pM}$ (lane 2) of ${ }^{125} \mathrm{I}-\mathrm{IL}-4$ alone and in the presence of unlabeled IL-4 (lane 3), IL-13 (lane 4), IL-2 (lane 5), and $\mathrm{mAb}$ CDw124 (anti-IL-4R $\alpha$, lane 6 ) and IL-2R $\gamma$ mAb 3G11 (lane 7). (D) FPA fibroblasts were incubated with $1 \mathrm{nM}$ of ${ }^{125} \mathrm{I}-\mathrm{IL}-4$ either alone (lane 1) or in the presence of unlabeled IL-4 (lane 2), IL-13 (lane 3), IL-2 (lane 4), and mAbs CDw124 (anti-IL-4R $\alpha$, lane 5) and 3G11 (anti-IL-2R $\gamma$, lane 6). Numbers represent marker molecular weights (kD). Arrows, Receptor chain subunit bound to IL-4. Each autoradiogram is representative of at least three different experiments. sence of cytokine release and corresponding gene transcription (Table III). Moreover, SCF and eotaxin transcripts were also present in all three types of fibroblasts (Fig. 1). However, MCP-4 transcripts were detected in ICIG7 and CCL202 but not in FPA fibroblasts (Fig. 1), while IL-3 transcripts were revealed in CCL202 but not in the two other fibroblast populations (data not shown).

Presence of IL-4 and IL-13 receptors in human lung fibroblasts. As illustrated in Fig. $2 A$, the specific transcripts for IL$4 \mathrm{R} \alpha$ (335 bp) and for IL-13R $\alpha 1$ (358 bp) were detected in all three human lung fibroblasts by RT-PCR. The presence of IL$4 \mathrm{R} \alpha$ chain was further evidenced by flow cytometry (Fig. 2 B). By contrast, the specific transcripts for IL-13R $\alpha 2$ (426 bp) were detected in CCL202 but not in ICIG7 and FPA fibroblasts (Fig. $2 A$ ). Conversely, the specific transcripts for IL$2 \mathrm{R} \gamma(481 \mathrm{bp})$ were present in FPA fibroblasts but not in the two others. Flow cytometric analysis confirmed the restricted surface expression of IL-13R $\alpha 2$ and IL-2R $\gamma$ chain in CCL202 and FPA fibroblasts, respectively (Fig. $2 \mathrm{~B}$ ).

It is noteworthy that in ICIG7 and CCL202 fibroblasts, the IL-2R $\gamma$ chain transcripts were detected after incubating the cells with the protein synthesis inhibitor, cycloheximide (10 $\mu \mathrm{g} / \mathrm{ml})$. The same treatment also increased the intensity of the transcripts in FPA fibroblasts (Fig. $2 A$ ). It has been shown that the IL-2R $\gamma$ mRNA is unstable and short-lived (33). Our results support the notion that IL-2R $\gamma$ is a constitutive gene and indicate that in lung fibroblasts, there are different posttranscriptional regulatory mechanisms which can be overcome by inhibiting protein synthesis.

${ }^{125}$ I-IL-4 cross-linking to human lung fibroblasts. In ICIG7 cells, ${ }^{125}$ I-IL-4 (1 nM) was cross-linked to a heterodimeric complex composed of a band of $160 \mathrm{kD}$ and a diffuse band of 80 $90 \mathrm{kD}$ (Fig. 3, $A$ and $B$, lane 1 ). IL-4 is a $19-\mathrm{kD}$ protein; thus, the molecular mass of each cross-linked protein was $\sim 140$ 
ICIG7

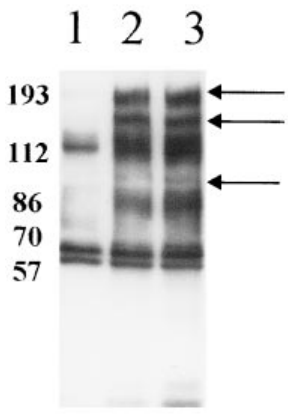

CCL202

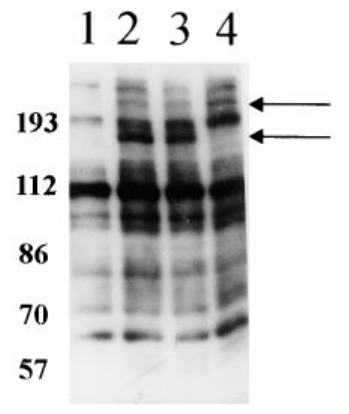

FPA

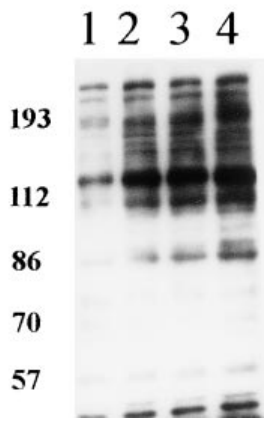

Figure 4. Tyrosine phosphorylation induced in human lung fibroblasts by IL-4 and IL-13. Cells were starved overnight and then stimulated with serum-free medium (lane 1), $100 \mathrm{ng} / \mathrm{ml}$ of either IL-4 (lane 2) or IL-13 (lane 3), and 10\% FCS (lane 4) for $10 \mathrm{~min}$ at $37^{\circ} \mathrm{C}$. The total cell lysates were separated on $7.5 \%$ or $5-17.5 \%$ SDS-PAGE, transferred to PVDF membranes, and then immunoblotted with antiP-Tyr mAb 4G10. Numbers represent marker molecular weights (kD). Arrows, Tyrosine-phosphorylated proteins induced by IL-4 and IL-13. Each autoradiogram is representative of at least three independent experiments. and $60 \mathrm{kD}$, respectively. The intensity of the two bands was strongly decreased after preincubation with a 100 -fold excess of unlabeled IL-4 (Fig. $3 A$, lane 4 , and Fig. $3 B$, lane 2 ) and IL-13 (Fig. $3 A$, lane 5). By contrast, preincubation with either IL-2 (Fig. 3 , lane 3), IL-15 (lane 4), or blocking mAbs to IL-2R $\beta$ (lane 5) and to IL-2R $\gamma$ (lane 6 ) did not affect the intensity of the two bands. From the above results, both IL-4R $\alpha$ (140-kD) and IL-13R $\alpha(60-\mathrm{kD})$ chains appeared to be present in ICIG7 fibroblasts. Furthermore, the decrease $(\sim 50 \%)$ in labeling seen after further incubation at $37^{\circ} \mathrm{C}$ (Fig. $3 \mathrm{~A}$, lane 3 ) indicates that the IL-4/IL-4R complex was internalized. Finally, the weaker labeling observed at 250 pM compared with $1 \mathrm{nM}$ of ${ }^{125} \mathrm{I}-\mathrm{IL}-4$ (Fig. $3 A$, lane 2) suggests the presence of a small number of high affinity IL-4 receptors in these cells.

In CCL202 fibroblasts, only the band of $160 \mathrm{kD}$ (IL-4/IL$4 \mathrm{R} \alpha$ ) was revealed (Fig. $3 C$, lane 1 ). The band intensity was abolished completely by unlabeled IL-4 (lane 3) and partially inhibited by either IL-13 (lane 4) or anti-IL-4R $\alpha$ mAb (lane 6 ). No changes were observed with IL-2 (lane 5) or anti-IL$2 \mathrm{R} \gamma \mathrm{mAb}$ (lane 7). The intense labeling still detected at 250 pM of ${ }^{125}$ I-IL-4 (lane 2) suggests the existence of a significant number of high affinity IL-4 receptors.
In FPA fibroblasts, a new band of $\sim 87 \mathrm{kD}$ was detected in addition to the two others seen in ICIG7 cells (Fig. $3 \mathrm{D}$, lane 1). Preincubation either with unlabeled IL-4 (lane 2) or antiIL-4R $\alpha \mathrm{mAb}$ (lane 5) exclusively affected the intensity of the 160-kD band (IL-4/IL-4R $\alpha$ ), whereas IL-13 (lane 3) decreased all three. Whereas IL-2 (lane 4) had no effect, the blocking anti-IL-2R $\gamma$ mAb (lane 6) specifically abolished the labeling of the $87-\mathrm{kD}$ band, indicating the presence of the IL-2R $\gamma$ chain (65 kD) in addition to IL-4R $\alpha$ and IL-13R $\alpha 1$ subunits.

Taken together, our data clearly demonstrated that all three distinct lung fibroblasts expressed IL-4/IL-13 receptors whose composition appeared to differ according to the type of fibroblast analyzed.

Induction of tyrosine phosphorylation by IL-4 and IL-13. To determine whether the binding of IL-4 or IL-13 to their receptors induced a signal transduction in lung fibroblasts, the phosphorylation of cell-associated proteins was analyzed by Western blot with the anti-P-Tyr mAb 4 G10 (Fig. 4). In ICIG7 fibroblasts, IL-4 (lane 2) and IL-13 (lane 3) induced the tyrosine phosphorylation of at least three proteins, of $\sim 90$ 100, 170-180, and 190-210 kD, compared with unstimulated cells (lane 1). In CCL202 fibroblasts, IL-4 and IL-13 induced the phosphorylation of another protein, of 200-210 kD (lanes

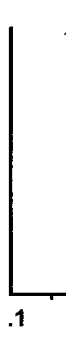

A

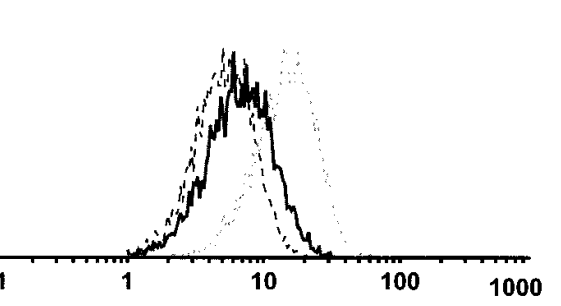

B

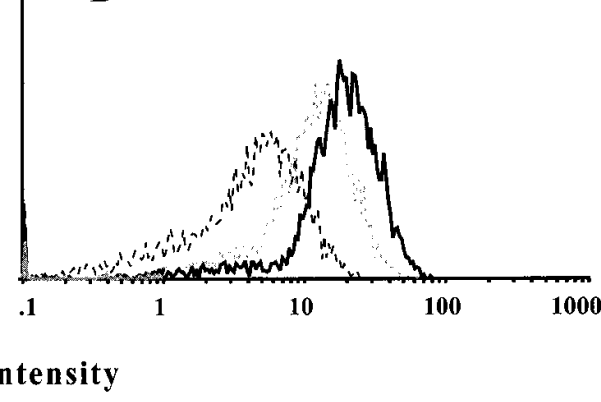

Figure 5. Increase in $\beta 1$ integrin expression in human lung fibroblasts by IL-4 and IL-13. ( $A$ ) $\beta 1$ integrin expression in ICIG7 fibroblasts left untreated (broken black line) or incubated with 50 (broken gray line) and $100 \mathrm{ng} / \mathrm{ml}$ (solid gray line) of IL-4 and $(B)$ with either $100 \mathrm{ng} / \mathrm{ml}$ IL-4 (solid gray line) or $10 \mathrm{ng} / \mathrm{ml}$ IL-13 (solid black line). Mean fluorescence intensity was determined with Cellquest software. Each histogram is representative of at least three different experiments. 

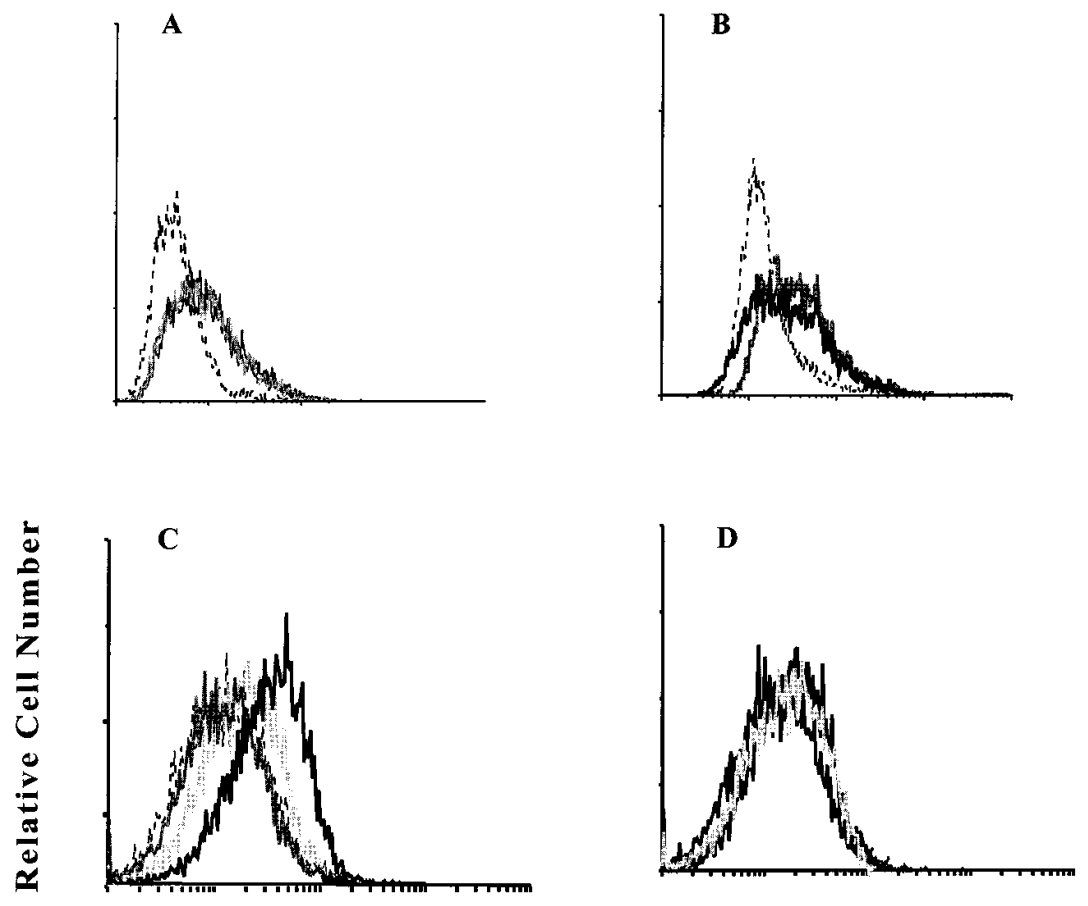

Figure 6. Differential modulation of VCAM-1 expression in human lung fibroblasts by IL-4 and IL-13. ( A) VCAM-1 expression in CCL202 fibroblasts left untreated (broken black line) and incubated with 0.5 (light gray solid line), 2.5 (dark gray solid line), and 50 (black solid line) $\mathrm{ng} / \mathrm{ml}$ of IL-4 and $(B)$ with either $100 \mathrm{ng} / \mathrm{ml}$ of IL-4 (thick gray line) or IL-13 (thick black line). (C) VCAM-1 expression in ICIG7 cells left untreated (broken black line) and incubated either with $100 \mathrm{ng} / \mathrm{ml}$ IL-4 (dark gray solid line), $0.5 \mathrm{ng} / \mathrm{ml} \mathrm{TNF-} \alpha$ (light gray solid line) alone and in combination (black solid line), or $(D)$ with $100 \mathrm{ng} / \mathrm{ml}$ IL-13 (black solid line) instead of IL-4. (E) VCAM-1 expression in FPA fibroblasts left untreated or incubated with either $100 \mathrm{ng} / \mathrm{ml} \mathrm{IL-4} \mathrm{(dark} \mathrm{gray} \mathrm{solid} \mathrm{line),}$ $2 \mathrm{ng} / \mathrm{ml} \mathrm{TNF}-\alpha$ (light gray solid line) alone and in combination (black solid line), or $(F)$ with $100 \mathrm{ng} / \mathrm{ml}$ IL-13 (black solid line) instead of IL-4. Mean fluorescence intensity was determined with Cellquest software. Each graph is representative Fluorescence Intensity of at least three different experiments.

2 and 3) in addition to the $170-180-\mathrm{kD}$ band seen in ICIG7 cells compared with serum-stimulated cells (lane 4). In FPA fibroblasts, an overall increase in protein phosphorylation was observed (lanes 2 and 3) that was to about the same extent as that observed under serum stimulation (lane 4).

Modulation of $\beta 1$ integrin and VCAM-1 expression by $I L-4$ and IL-13. IL-4 and IL-13 have been shown previously to modify the expression of different adhesion molecules in varied cell types (34-36). In ICIG7 fibroblasts, IL-4 induced a dose-dependent increase in the expression of $\beta 1$ integrin (Fig. 5 A). Similarly, IL-13 increased $\beta 1$ integrin expression, with a maximal effect at $10 \mathrm{ng} / \mathrm{ml}$ (Fig. $5 \mathrm{~B}$ ). No modulation was observed in the two other fibroblasts (data not shown).

In CCL202 fibroblasts, a significant increase in the level of VCAM-1 expression was observed with IL-4, even at very low amounts $(0.5 \mathrm{ng} / \mathrm{ml})$, and with IL-13 (Fig. 6, $A$ and $B$ ), whereas IL-4 and IL-13 had no effect in VCAM-1-unexpressing ICIG7 and FPA fibroblasts (Fig. 6, $C$ and $D$, and Fig. 6, $E$ and $F$, re- spectively). However, in such cells, VCAM-1 was expressed when high concentrations $(100 \mathrm{ng} / \mathrm{ml})$ of IL-4 but not IL-13 were combined with TNF- $\alpha(0.5-2 \mathrm{ng} / \mathrm{ml})$ (Fig. 6, $C$ and $E)$.

When the expression levels of two other adhesion molecules, intercellular adhesion molecule 1 and very late antigen 4, known to play an important role in asthma pathogenesis $(37,38)$, were analyzed, no change was detected in response to IL-4 and IL-13 (data not shown).

Modulation of IL-6 and MCP-1 production by IL-4 and $I L-13$. Among the various cytokines produced by the three types of fibroblasts (see Table III), IL-6 and MCP-1 are two important inflammatory cytokines involved in the pathogenesis of allergic inflammation. In ICIG7 fibroblasts, IL-6 production (left) was increased significantly by IL-4 and IL-13 after a 48- and 72-h treatment (Fig. $7 A$ ), whereas no changes were observed in CCL202 and FPA cells (Fig. 7, $B$ and $C$ ). By contrast, upregulation in MCP-1 production (right) was observed in all three fibroblasts after 48- and 72-h treatment with IL-4. 


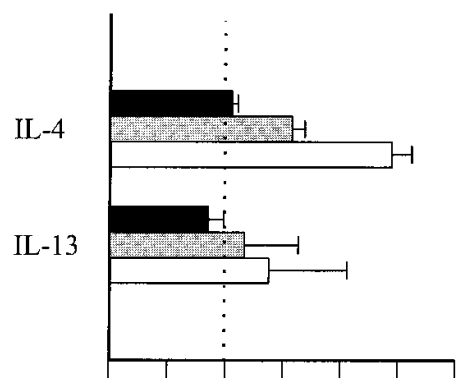

$\mathbf{A}$

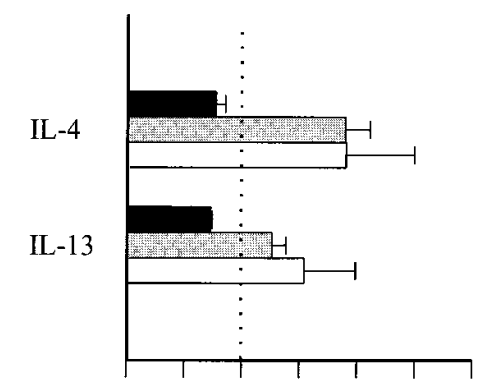

B

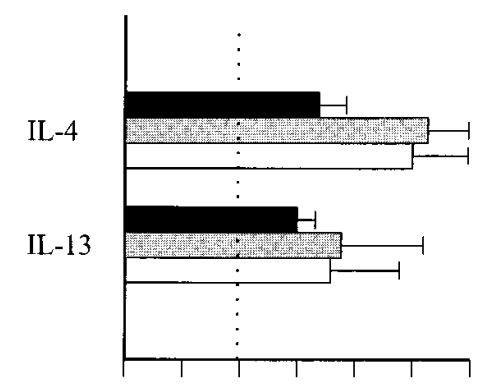

C

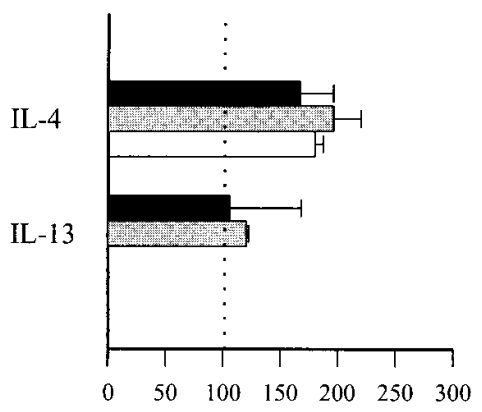

$\%$ Increase in $\mathrm{MCP}-1$ production
Figure 7. Modulation of IL-6 and MCP-1 production in human lung fibroblasts by IL-4 and IL-13. ICIG7 ( $A)$, CCL202 (B), and FPA $(C)$ fibroblasts were incubated with $100 \mathrm{ng} / \mathrm{ml}$ of either IL-4 or IL-13 for 24 (white bars), 48 (black bars), and 72 (gray bars) h. Histograms represent the percent increase in IL-6 (left) and MCP-1 (right) production calculated from the ratio, cytokine-stimulated cell production/unstimulated cell production $\times 100$. Dotted lines, Control level. Each value represents the mean \pm SEM of three different experiments.
However, the stimulation was less significant with IL-13 than with IL-4 and was detected in CCL202 but not ICIG7 and FPA fibroblasts (Fig. $7 \mathrm{~B}$ ).

\section{Discussion}

Although distinct subpopulations of fibroblasts have been identified in murine lung fibroblasts by different phenotypic characteristics and functions $(11,12)$, the possible involvement of specific fibroblastic subsets in the development of human chronic inflammatory airway diseases such as asthma as well as the role of the immune factors regulating this cellular interplay are, at present, poorly understood. We provide evidence here that IL-4 and IL-13, which are produced by Th2 lymphocytes in the initial phase of the asthmatic process, may be active not only on inflammatory cells but also on different lung fibroblast populations, transforming these target cells into effectors of the inflammatory process.

We demonstrate that human lung fibroblasts derived from fetal and adult normal tissue and from a Th2-type stromal reaction maintain distinct phenotypes and functions in vitro. Thus, fetal ICIG7 fibroblasts differ from adult CCL202 cells in that they express ED-B fibronectin variant and spontaneously produce GM-CSF, but lack VCAM-1 expression and IL-3 transcription. Likewise, differences are found between stromaderived FPA fibroblasts and normal CCL202 cells in that FPA cells express $\alpha$-SMA, a marker of the activation of fibroblasts into myofibroblasts, ED-B fibronectin, an oncofetal marker of myofibroblasts present in tumor stroma and fibrotic tissues $(29,32,39)$, and CD40 antigen, but lack CD4 and c-kit expression and MCP-4 transcription. Despite these differences, the three fibroblasts also share some characteristics. For example, they all spontaneously produce a number of cytokines capable of activating inflammatory cells (i.e., IL-6, IL-8, and MCP-1) at levels similar to those scored in human eosinophils and monocytes (23). All fibroblasts also express the transcripts for SCF and eotaxin, an eosinophil-selective chemokine which plays a major role in airway hyperresponsiveness (24).

The differences we found in the profile of cytokines and chemokines involved in proinflammatory processes (IL-3, IL-6, IL-11, and GM-CSF) or eosinophil recruitment (MCP-4) as well as in molecules interacting and activating $\mathrm{T}$ (CD4) and $\mathrm{B}$ (CD40) lymphocytes or eosinophils (VCAM-1) between the three fibroblastic populations can lead to different patterns of 
immunoregulation. In this context, we have observed that an eosinophilic cell line, Eol-3, was able to adhere spontaneously to CCL202 but not to ICIG7 and FPA fibroblasts (data not shown). It is also likely that the differential expression of HLA class II we detect in the three fibroblasts may influence the homotypic and heterotypic cell-cell interactions mediated by CD4/HLA class II.

Regarding the interactions between human lung fibroblasts and IL-4/IL-13, we show that the three populations express functional but different receptors. We found by RT-PCR that the transcripts for IL-4R $\alpha$ and IL-13R $\alpha 1$ are present in all three types of fibroblasts. The presence of IL-4R $\alpha$ chain was further evidenced by flow cytometry. Cross-linking experiments with ${ }^{125}$ I-IL-4 reveal different patterns of binding according to the type of fibroblasts. Thus, in ICIG7 fibroblasts, the size of the two chains recognized by ${ }^{125}$ I-IL-4 and the total IL-4 binding inhibition by IL-4/IL-13 suggest that these two chains are IL-4R $\alpha$ and IL-13R $\alpha 1$, which form a heterodimer able to bind IL-4 and IL-13 (40, 41). In CCL202 fibroblasts, ${ }^{125}$ I-IL-4 only binds to a single chain with a migratory pattern corresponding to the IL-4R $\alpha$. On the other hand, the presence of IL-13R $\alpha 1$ transcript as well as the partial inhibition of ${ }^{125} \mathrm{I}-$ IL-4 binding by IL-13 suggest the involvement of this chain in the composition of the IL-4 receptor (42). Another difference between ICIG7 and CCL202 fibroblasts is evidenced by the complete and partial inhibition of ${ }^{125}$ I-IL-4 binding to ICIG7 and CCL202 cells, respectively, by the same amount of IL-13. This can be explained by the presence of the IL-13R $\alpha 2$ chain that we detect by RT-PCR and flow cytometry and which has been reported to bind IL-13 but not IL-4 with high affinity (43), thereby partially sequestering IL-13 in competition experiments. On the other hand, we cannot exclude the presence of IL-4R $\alpha$ homodimers in CCL202 fibroblasts in light of recent reports on chimeric receptors (44-46).

In addition to the two IL-4R $\alpha$ and IL-13R $\alpha 1$ chains, IL-4 also binds, in FPA cells, to a third chain, corresponding to the IL-2R $\gamma$ chain whose transcription and expression is also detected by RT-PCR and flow cytometry. Moreover, the total inhibition of ${ }^{125} \mathrm{I}-\mathrm{IL}-4$ binding to this third chain by an antiIL-2R $\gamma$ blocking $\mathrm{mAb}$ as well as the partial inhibition of the cytokine to the IL- $4 \mathrm{R} \alpha$ and IL-13R $\alpha 1$ subunits by unlabeled IL-4 and anti-IL-4R $\alpha$ mAb suggest the existence of a heterotrimer IL-4R $\alpha /$ IL-13R $\alpha 1 /$ IL-2R $\gamma$ in FPA fibroblasts and the possible involvement of the IL-2R $\gamma$ chain in its stabilization. Finally, we show that IL-13 partially inhibits the binding of IL-4 to the three subunits, indicating that this cytokine also efficiently recognizes the heterotrimer and physically interacts with the IL-2R $\gamma$ chain, as reported recently (47). For the first time, our data provide evidence for the presence of a heterotrimer IL-4R $\alpha /$ IL-13R $\alpha 1 /$ IL-2R $\gamma$ able to bind not only IL-4 but also IL-13 in nonexperimentally modified cells, and for a spontaneous membrane expression of the IL-2R $\gamma$ chain in human fibroblasts.

The different IL-4/IL-13 receptors we detect in the three human lung fibroblasts appear to be functional, since both cytokines trigger a specific signal transduction which is somewhat different according to the fibroblast population analyzed. Thus, tyrosine phosphorylation of three proteins of $\sim 90-100$, $170-180$, and $190-200 \mathrm{kD}$ is induced in ICIG7 fibroblasts, whereas two proteins, of $170-180$ and $200-210 \mathrm{kD}$, are detected in CLL202 cells. In FPA fibroblasts, an overall increase in protein phosphorylation is observed in response to IL-4 and
IL-13. Therefore, our results suggest a specific metabolic action of the two cytokines in human lung fibroblasts.

The differences in signal transduction induced in the three types of fibroblasts by IL-4 and IL-13 seem to be associated with different biological effects. For instance, differences in the regulation in adhesion molecules are observed among the three types of fibroblasts. Thus, although a significant increase in VCAM-1 expression is noted in CCL202 fibroblasts after stimulation with IL-4 and IL-13, no VCAM-1 expression is induced in ICIG7 and FPA fibroblasts, which both lack spontaneous expression, unless IL-4 but not IL-13 are combined with TNF- $\alpha$. Therefore, the two cytokines IL-4 and IL-13 may contribute to a differential activation of the VCAM-1 adhesion pathway, thereby allowing the selective infiltration and homing of eosinophils in the bronchial wall $(34-36,48)$. Another difference is also evident in the selective upregulation of $\beta 1$ integrin induced by IL-4 and IL-13 in actively growing ICIG7 fibroblasts but not in the two other cells. This effect can lead to altered interactions between fibroblasts and matrix components such as collagen and fibronectin $(49,50)$, which are generally overexpressed in fibrotic tissues and play an important role in the remodeling of lung architecture and activation of signal transduction. Additionally, the differential modulation in cytokine and chemokine production that we found in human lung fibroblasts in response to IL-4 and IL-13 may also have important implications in lung pathologies. For instance, the increased production of IL-6 observed in ICIG7 cells can activate autocrine loops involved in the evolution of fibrosis, and can also positively regulate survival and histamine release in human mast cells during allergic reactions (51). On the other hand, IL-4 increases MCP-1 production in the three fibroblasts at levels comparable to those observed in activated monocytes and eosinophils (23). This may be important, since MCP-1 plays a role in fibrosis (52) and in allergic inflammation through induction of chemotaxis and activation of basophils (23).

Overall, our results clearly demonstrate that IL-4 and IL-13 act on human lung fibroblasts by increasing the expression of cell surface $\beta 1$ integrin and VCAM- 1 adhesion molecules and the secretion of some of the cytokines/chemokines implicated in inflammatory and asthmatic pathologies. Our data support the hypothesis that lung resident cells such as fibroblasts behave not only as target cells but also as important effector cells in the regulation of the asthmatic process in response to IL-4 and IL-13. If the fibroblastic populations we have characterized in vitro do have in vivo counterparts, they could play a pivotal role in the amplification of the inflammatory cascade in response, for instance, to IL-4 or IL-13. Through their differential modulation of adhesion molecules and inflammatory cytokine and chemokine release, they could act separately or, more probably, integrate their functions during lung remodeling processes.

\section{Acknowledgments}

We thank Drs. A. Minty, J. Ritz, N. Vita, and J. Withness for their generous assistance in providing biological reagents. We are grateful to F. Lenaour and J. Vedrenne for their support.

This work was supported by the Société Française d'Hématologie and the Association pour la Recherche sur le Cancer, grant 3055. C. Doucet is a recipient of a Ministère de la Recherche et de l'Enseignement fellowship. 


\section{References}

1. Roche, W.R., R. Beasley, J.H. Williams, and S.T. Holgate. 1989. Subepithelial fibrosis in the bronchi of asthmatics. Lancet. 1:520-523.

2. Bousquet, J., P. Chanez, J.-Y. Lacoste, G. Barneon, N. Ghavanian, I. Enander, P. Venge, S. Ahlstedt, J. Simony-Lafontaine, P. Godard, and F.-B. Michel. 1990. Eosinophilic inflammation in asthma. N. Engl. J. Med. 323:10331039.

3. Broide, D.H., G.J. Gleich, A.J. Cuomo, D.A. Coburn, E.C. Federman, L.B. Schwartz, and S.I. Wasserman. 1991. Evidence of ongoing mast cell and eosinophil degranulation in symptomatic asthma airway. J. Allergy Clin. Immunol. 88:637-648.

4. Robinson, D.S., O. Hamid, S. Ying, A. Tsicopoulos, J. Barkans, A.M. Bentley, C. Corrigan, S.R. Durham, and A.B. Kay. 1992. Predominant Th2-like bronchoalveolar T-lymphocyte population in atopic asthma. N. Engl. J. Med. 326:298-304

5. Woodley, K.L., E. Adelroth, M.J. Woolley, R. Ellis, M. Jordana, and P.M. O'Byrne. 1994. Granulocyte-macrophage colony-stimulating factor, eosinophils and eosinophil cationic protein in subjects with and without mild, stable, atopic asthma. Eur. Resp. J. 7:1576-1584.

6. Drazen, J.M., J.P. Arm, and K.F. Austen. 1996. Sorting out the cytokines of asthma. J. Exp. Med. 183:1-5.

7. Derdak, S., D.P. Penney, P. Keng, M. Felch, D. Brown, and R.P. Phipps. 1992. Collagen and fibronectin production by Thy $1+$ and Thy $1-$ lung fibroblast subpopulations. Am. J. Physiol. 263:L283-L290.

8. Postlethwaite, A.E., M.A. Holness, H. Katai, and R. Raghow. 1992. Human fibroblasts synthesize elevated levels of extracellular matrix proteins in response to interleukin 4. J. Clin. Invest. 90:1479-1485.

9. Makhluf, H.A., J. Stepniakowska, S. Hoffman, E. Smith, E.C. LeRoy, and M. Trojanowska. 1996. IL-4 upregulates tenascin synthesis in scleroderma and healthy skin fibroblasts. J. Investig. Dermatol. 107:856-859.

10. Schmitt-Gräff, A., A. Desmoulière, and G. Gabbiani. 1994. Heterogeneity of myofibroblast phenotypic features: an example of fibroblastic cell plasticity. Virchows Arch. 425:3-24.

11. Phipps, R.P., D.P. Penney, P. Keng, H. Quill, A. Paxhia, S. Derdak, and M.E. Felch. 1989. Characterization of two major populations of lung fibroblasts: distinguishing morphology and discordant display of Thy 1 and class II MHC. Am. J. Respir. Cell Mol. Biol. 1:65-74.

12. Derdak, S., P. Dixon, H. Watts, P. Penny, and R.P. Phipps. 1991. CD4 expression in lung fibroblasts. Lancet. 337:374-377.

13. Plaisance, S., E. Rubinstein, A. Alileche, P. Benoit, C. Jasmin, and B. Azzarone. 1993. The IL-2 receptor present on human embryonic fibroblasts is functional in the absence of p64/IL-2R gamma chain. Int. Immunol. 5:843-848.

14. Kondo, M., T. Takeshita, N. Ishii, M. Nakamura, S. Watanabe, K. Arai, and K. Sugamura. 1993. Sharing of the interleukin-2 (IL-2) receptor $\gamma$ chain between receptors for IL-2 and IL-4. Science. 262:1874-1877.

15. Russell, S.M., A.D. Keegan, N. Harada, Y. Nakamura, M. Naguchi, P. Leland, M.C. Friedmann, A. Miyajima, R.K. Puri, W.E. Paul, and W.J. Leonard. 1993. Interleukin-2 receptor $\gamma$ chain: a functional component of the interleukin-4 receptor. Science. 262:1880-1883.

16. Kondo, M., T. Takeshita, M. Higuchi, M. Nakamura, T. Sudo, S.I. Nishikawa, and K. Sugamura. 1994. Functional participation of the IL-2 receptor $\gamma$ chain in IL-7 receptor complexes. Science. 263:1453-1454.

17. Giri, J.G., M. Ahdieh, J. Eisenman, K. Shanebeck, K. Grabstein, S. Kumaki, A. Namen, L.S. Park, D. Cosman, and D. Anderson. 1994. Utilization of the $\beta$ and $\gamma$ chains of the IL-2 receptor by the novel cytokine IL-15. EMBO (Eur. Mol. Biol. Organ.) J. 13:2822-2830.

18. Sugamura, K., H. Asao, M. Kondo, N. Tanaka, N. Ishii, M. Nakamura, and T. Takeshita. 1995. The common $\gamma$-chain for multiple cytokine receptors. Adv. Immunol. 59:225-277.

19. Obiri, N.I., W. Debinsky, W.J. Leonard, and R.K. Puri. 1995. Receptor for interleukin 13. Interaction with interleukin 4 by a mechanism that does not involve the common $\gamma$ chain shared by receptors for interleukin $2,4,7,9$, and 15. J. Biol. Chem. 270:8797-8804.

20. Vita, N., S. Lefort, P. Laurent, D. Caput, and P. Ferrara. 1995. Characterization and comparison of the interleukin 13 receptor with the interleukin 4 receptor on several cell types. J. Biol. Chem. 270:3512-3517.

21. Zurawski, G., and J.E. de Vries. 1994. Interleukin 13, an interleukin 4-like cytokine that acts on monocytes and B cells, but not on T cells. Immunol. Today. 15:19-26.

22. Sappino, A.P., W. Schürch, and G. Gabbiani. 1990. Differentiation repertoire of fibroblastic cells. Expression of cytoskeletal proteins as markers of phenotypic modulations. Lab. Invest. 63:144-161.

23. Izumi, S., K. Hirai, M. Miyamasu, Y. Takahashi, Y. Misaki, T. Takaishi, Y. Morita, K. Matsushima, N. Ida, H. Nakamura, T. Kasahara, and K. Ito. 1997. Expression and regulation of monocyte chemoattractant protein-1 by human eosinophils. Eur. J. Immunol. 27:816-824.

24. Jose, P.J., D.A. Griffiths-Johnson, P.D. Collins, D.T. Walsh, R. Moqbel, N.F. Totty, O. Truong, J.J. Hsuan, and T.J. Williams. 1994. Eotaxin: a potent eosinophil chemoattractant cytokine detected in a guinea pig model of allergic airways inflammation. J. Exp. Med. 179:881-887.

25. Chvatchko, Y., M.H. Kosco-Vilbois, S. Herren, J. Lefort, and J.-Y.
Bonnefoy. 1996. Germinal center formation and local immunoglobulin E (IgE) production in the lung after an airway antigenic challenge. J. Exp. Med. 184 2353-2360.

26. McWilliams, A.S., S. Napoli, A.M. Marsh, F.L. Pemper, D.J. Nelson, C.L. Pimm, P.A. Stumbles, T.N.C. Wells, and P.G. Holt. 1996. Dendritic cells are recruited into the airway epithelium during the inflammatory response to a broad spectrum of stimuli. J. Exp. Med. 184:2429-2432.

27. Azzarone, B., H. Suarez, M. Mingari, L. Moretta, and A.S. Fauci. 1984. 4F2 monoclonal antibody recognizes a surface antigen on spread human fibroblasts of embryonic but not adult origin. J. Cell Biol. 98:1133-1137.

28. Brouty-Boyé, D., H. Raux, B. Azzarone, A. Tamboise, S. Béranger, V. Magnien, I. Pihan, L. Zardi, and L. Israël. 1991. Fetal myofibroblast-like cells isolated from post-radiation fibrosis in human breast cancer. Int. J. Cancer. 47: 697-702.

29. Stellato, C., P. Collins, P.D. Ponath, D. Soler, W. Newman, G. La Rosa, H. Li, J. White, L.M. Schwiebert, C. Bickel, M. Liu, B.S. Bochner, T. Williams, and R.P. Schleimer. 1997. Production of the novel C-C chemokine MCP-4 by airway cells and comparison of its biological activity to other C-C chemokines. J. Clin. Invest. 99:926-936.

30. Colamonici, O.R., L.M. Neckers, and A. Rosolen. 1990. Putative $\gamma$-subunit of the IL-2 receptor is detected in low, intermediate, and high affinity IL-2 receptor-bearing cells. J. Immunol. 145:155-160.

31. Lefort, S., N. Vita, R. Reeb, D. Caput, and P. Ferrara. 1995. IL-13 and IL-4 share signal transduction elements as well as receptor components in TF-1 cells. FEBS (Fed. Eur. Biochem. Soc.) Lett. 366:122-126.

32. Zardi, L., B. Carnemolla, A. Siri, T.E. Peterson, P. Giovanni, G. Sebastio, and F.E. Baralle. 1987. Transformed human cells produce a new fibronectin isoform by preferential alternative splicing of a previously unobserved exon. EMBO (Eur. Mol. Biol. Organ.) J. 6:2337-2342.

33. Bosco, M.C., I. Espinoza-Delgado, M. Schwabe, G.L. Gusella, D.L. Longo, K. Sugamura, and L. Varesio. 1994. Regulation by interleukin-2 (IL-2) and interferon $\gamma$ of IL-2 receptor $\gamma$ chain gene expression in human monocytes. Blood. 83:2995-3002.

34. Schleimer, R.P., S.A. Sterbinsky, J. Kaiser, C.A. Bickel, D.A. Klunk, K. Tomioka, W. Newman, F.W. Luscinskas, M.A. Gimbrone, B.W. McIntire, and B.S. Bochner. 1992. IL-4 induces adherence of human eosinophils and basophils but not of neutrophils to endothelium. Association with expression of VCAM-1. J. Immunol. 148:1086-1092.

35. Sironi, M., F.L. Sciacca, C. Matteucci, M. Conni, A. Vecchi, S. Bernasconi, A. Minty, D. Caput, P. Ferrara, and F. Colotta. 1994. Regulation of endothelial and mesothelial cell function by interleukin-13: selective induction of vascular cell adhesion molecule- 1 and amplification of interleukin- 6 production. Blood. 84:1913-1921.

36. Bochner, B.S., D.A. Klunk, S.A. Sterbinsky, R.L. Coffman, and R.P. Schleimer. 1995. IL-13 selectively induces vascular cell adhesion molecule-1 expression on human endothelial cells. J. Immunol. 154:799-803.

37. Wegner, C.D., R.H. Gundel, P. Reilly, N. Haynes, L.G. Letts, and R. Rothlein. 1990. Intercellular adhesion molecule-1 (ICAM-1) in the pathogenesis of asthma. Science. 247:456-459.

38. Paolieri, F., M. Battifora, A.M. Riccio, G. Pesce, G.W. Canonica, and M. Bagnasco. 1997. Intercellular adhesion molecule-1 on cultured human epithelial cell lines: influence of proinflammatory cytokines. Allergy. 52:521-531.

39. Brouty-Boyé, D., and V. Magnien. 1994. Myofibroblast and concurrent ED-B fibronectin phenotype in human stromal cells cultured from non-malignant and malignant breast tissue. Eur. J. Cancer. 30A:66-73.

40. Hilton, D.G., J.-G. Zhang, D. Metcalf, W.S. Alexander, N.A. Nicola, and T.A. Willson. 1996. Cloning and characterization of a binding subunit of the interleukin 13 receptor that is also a component of the interleukin 4 receptor. Proc. Natl. Acad. Sci. USA. 93:497-501.

41. Zurawski, S.M., F.J. Vega, B. Huyghe, and G. Zurawski. 1993. Receptors for interleukin-13 and interleukin-4 are complex and share a novel component that functions in signal transduction. EMBO (Eur. Mol. Biol. Organ.) J. 12:2663-2670.

42. Aman, M.J., N. Tayebi, N.I. Obiri, R.K. Puri, W.S. Modi, and W.J. Leonard. 1996. cDNA cloning and characterization of the human interleukin 13 receptor $\alpha$ chain. J. Biol. Chem. 271:29265-29270.

43. Caput, D., P. Laurent, M. Kaghad, J.-M. Lelias, S. Lefort, N. Vita, and P. Ferrara. 1996. Cloning and characterization of a specific interleukin (IL)-13 binding protein structurally related to the IL-5 receptor $\alpha$ chain. J. Biol. Chem. 271:16921-16926.

44. Kammer, W., A. Lischke, R. Moriggl, B. Groner, A. Ziemiecki, C.B Gurniak, L.J. Berg, and K. Friedrich. 1996. Homodimerization of interleukin-4 receptor $\alpha$ chain can induce intracellular signaling. J. Biol. Chem. 271:23634 23637 .

45. Lai, S.Y., J. Molden, K.D. Liu, J.M. Puck, M.D. White, and M.A. Goldsmith. 1996. Interleukin-4-specific signal transduction events are driven by homotypic interactions of the interleukin-4 receptor $\alpha$ subunit. EMBO (Eur. Mol. Biol. Organ.) J. 15:4506-4514.

46. Reichel, M., B.H. Nelson, P.D. Greenberg, and P. Rothman. 1997. The IL-4 receptor $\alpha$-chain cytoplasmic domain is sufficient for activation of JAK-1 and STAT6 and the induction of IL-4-specific gene expression. J. Immunol. 158:5860-5867. 
47. Malabarba, M.G., H. Rui, H.H. Deutsch, J. Chung, F.S. Kalthoff, W.L. Farrar, and R.A. Kirken. 1996. Interleukin-13 is a potent activator of JAK3 and STAT6 in cells expressing interleukin-2 receptor- $\gamma$ and interleukin-4 receptor- $\alpha$. Biochem. J. 319:865-872.

48. Rochester, C.L., S.J. Ackerman, T. Zheng, and J.A. Elias. 1996. Eosinophil-fibroblast interactions. J. Immunol. 156:4449-4456.

49. Lee, W., J. Sodek, and C.A.G. McCulloch. 1996. Role of integrins in regulation of collagen phagocytosis by human fibroblasts. J. Cell. Physiol. 168: 695-704

50. Spurzem, J.R. 1996. Function at the junction: dynamic interactions be- tween lung cells and extracellular matrix. Thorax. 51:956-958.

51. Yanagida, M., H. Fukamachi, K. Ohgami, T. Kuwaki, H. Ishii, H. Uzumaki, K. Amano, T. Tokiwa, H. Mitsui, H. Saito, et al. 1995. Effects of T-helper 2-type cytokines, interleukin-3 (IL-3), IL-4, IL-5, and IL-6 on the survival of cultured human mast cells. Blood. 86:3705-3714.

52. Lloyd, C.M., A.W. Minto, M.E. Dorf, A. Proudfoot, T.N.C. Wells, D.J Salant, and J.-C. Gutierrez-Ramos. 1997. RANTES and monocyte chemoattractant protein-1 (MCP-1) play an important role in the inflammatory phase of crescentic nephritis, but only MCP-1 is involved in crescent formation and interstitial fibrosis. J. Exp. Med. 185:1371-1380. 